\title{
THE BELORUSSIAN FACTOR IN THE GENESIS OF THE MODERN LITHUANIAN STATE, 1915-1917
}

\author{
EDMUNDAS GIMŽAUSKAS
}

\begin{abstract}
The paper is devoted to a relatively recently researched subject - the relations between the Lithuanians and the Belorussians and the role of the latter in the genesis of the Lithuanian state in the early twentieth century.

At the start of the First World War in the German-occupied regions there was a chance to re-establish the Republic of the Two Nations for the first time after 1795. However, that was not the German intention. Initially they supported only the illusion of the re-establishment of Lithuanian statehood in the lands of the former Grand Duchy of Lithuania. In this policy there was also some space for the rudiments of the political activity of Lithuanian and Belorussian intellectuals. Since the beginning of the 'Los von Russland' Campaign of 1916 it is possible to trace certain open efforts to obtain Lithuanian and Belorussian statehood. In the Lithuanian political struggle formulas of historical and ethnic statehood were applied taking into consideration the practical political manoeuvres of the warring countries. After the declaration of Polish statehood on 5 November 1916 the ethnic model became more important. In the east an ethnic Lithuanian state was to coincide with the historic 'Lithuania Proper'. That was a basis for more or less constructive relations with the Belorussians, who also preferred to adhere to the historical formula. After the February Revolution, when the Belorussians started requiring the historical statehood of the whole of the GDL, contacts were broken, and they were renewed in the autumn of 1917 after the election of the Lithuanian Council (Taryba).
\end{abstract}

The territories inhabited by the Lithuanians and Belorussians were engulfed by the World War in the summer and autumn of 1915, when the Germans managed to occupy nearly all Lithuanian and a part of the Belorussian lands. In October the front line became stable, extending along the river Daugava (Dvina) up to Daugavpils, then by Lake Narutis (Narach), the river Berezina, Pinsk, to the river Pripet, across the Polesie marshes, via Lutsk and Tarnopol to Chernovtsy. The Germans did not yet have any definite programme of activities regarding the occupied territories. Researchers are 
inclined to distinguish at least five conceptions current among the then German ruling circles: a) annexation, b) the 'Central European' projects, c) the Polish (partly 'Central European'), d) 'Eastern European', and e) the Russian concept. ${ }^{1}$ Correspondingly the future of the occupied territories could fluctuate between utter annexation and their return to Russia. Besides, quite prominent was the idea of the satellite states of the German bloc. Its rise was conditioned by the growth of nationalism, the so-called "national factor' in Europe. Besides, the Germans were obliged to take into account the historic (state) law as a basis for the reconstruction of a state, destroyed by force, which in this case was the Republic of the Two Nations, which had ceased to exist in 1795. On the other hand, the very nature of the united state implied a great collision for a new national statehood. In their own activity the Germans created conditions for the definition of the contemporary territorial boundaries of the Lithuanians and the Belorussians (and respectively for their statehood) by establishing Oberost, a peculiar administrative unit of the occupied territory on 4 September 1915; by its shape and contours it resembled the Grand Duchy of Lithuania in $1793-1795 .^{2}$

Meanwhile, the territory of the Oberost reminded the Lithuanian intellectuals of the so-called 'Lithuania Proper' rather than of the GDL. According to a well-known public figure of independent inter-war Lithuania, the geographer Kazys Pakštas, Tikroji Lietuva 'Lithuania Proper' has been known since the new administrative division of the GDL of $1566 .^{3}$ Since then the palatinates of Vilnius and Trakai were referred to as Lithuania Propria (Lat.), Litwa Rdzenna or Litwa Właściwa (Pol.) and Коренная Литва (Russ.) in Lithuanian documents and often in maps. The Lithuanians themselves meant by this term the Duchy of Žemaitija, too. ${ }^{4}$ Paradoxically, it was the Russians who ensured the survival of the term 'Lithuania Propria' throughout the entire nineteenth century by using it in the context of strengthening the empire (until finally the Lithua-

1 R. Lopata, 'Lietuvos valstybingumo raida 1914-1918 metais', Lietuviu atgimimo studijos, t. 9 (Vilnius, 1996), pp. 17-18.

2 Ibid., p. 65.

${ }^{3}$ K. Pakštas, 'Gudijos santykis su Lietuva', Lietuvos sienu raida: mokslo duomenys apie lietuviu tauta, jos valstybe ir sienas, sud. A. Liekis, kn. 2 (Vilnius, 1997), p. 320.

${ }^{4}$ Ibid. 
nian intelligentsia appropriated the term and made it an object of its own activity). When the tsarist authorities forbade the use of the word 'Lithuania' in official publications in 1840, Russian scholarship did not follow suit and continued calling the gubernias of Kaunas, Vilnius, Grodno and sometimes even Suvalkai Lithuanian gubernias, and that was practised until the war of $1914 . .^{5}$ Among the Lithuanians these four gubernias were conceived very broadly as Lithuanian on ethnic grounds (language, origin, customs, etc.). ${ }^{6}$ That was particularly characteristic of Lithuanian conservatives (the Nationalists and Christian Democrats), according to whom the territory of these four gubernias had been inhabited by Lithuanian tribes since olden times. ${ }^{7}$ Meanwhile the Lithuanian radicals (the Democrats and Social Democrats) understood these four gubernias in a narrowly historical sense. The radicals seem to have considered that territory united by a peculiar scarcely tangible culture, standing above other local ethnic cultures since the times of the GDL. Due to a more dynamic perception of the nation the territorial programme of the radicals was more receptive to corrections. ${ }^{8}$

At the end of 1915 the Germans did not give priority to any particular concept for the future of Oberost, considering that such a move could damage a strategic separate treaty with Russia advocated by the chancellor, Theobald Bethmann Hollweg. ${ }^{9}$ For the time being the Germans decided to support the illusion of Lithuania, consisting of four gubernias and to conduct more thorough studies of the territories. The occupational period between 1915 and 1916 acquired the name of 'the period of liberal occupation'. ${ }^{10}$ Although on Paul von Hindenburg's orders all political activity was banned, ${ }^{11}$ that instruction was followed very flexibly in accordance with the political situation. The publication of the Belorussian newspaper

${ }^{5}$ Ibid., p. 333.

${ }^{6}$ Č. Laurinavičius, Lietuvos-Sovietu Rusijos taikos sutartis (Vilnius, 1992), pp. 101-102.

${ }^{7}$ Antanas Smetona should be accredited with the greatest merits in elaborating the Lithuanian character of the four gubernias; cf. A. Smetona, 'Lietuvos etnografijos ribos', Vairas, no. 16, 30 Nov. 1914, pp. 2-8; idem, 'Skaitmenų šviesoje', Vairas, no. 2, 16 Jan. 1915 , pp. 23-26. This issue was examined most meticulously by Smetona in emigration during WWII in 'Lithuania Propria'.

${ }^{8}$ Laurinavičius, Lietuvos-Sovietu Rusijos taikos sutartis, pp. 101-102.

${ }^{9}$ Lopata, 'Lietuvos valstybingumo raida', p 62-63.

${ }^{10}$ Ibid., p. 67.

11 J. Ochmański, Historia Litwy (Wrocław-Warsaw, 1982), p. 277. 
Homan, the functioning of the Belorussian society to support war victims, the Belorussian club in Vilnius and of other numerous cultural and educational organizations and institutions strengthened the common trends of Belorussian consolidation. ${ }^{12}$ Early in 1916 a political Belorussian national committee was established in Vilnius. Socialistminded representatives dominated it. ${ }^{13}$

When the Germans started supporting the illusion of the Lithuanian state in the contours of Oberost, local politicians actively participated in the re-invigoration of the ideas of historical statehood. For the first time in the Vilnius region a joint partly overt attitude of the nationalities of the region (including the Belorussians) to the issues of statehood was expressed in a universal of the Provisional Council of the Confederation of the GDL, which was published in four languages on 15 December 1915. The document contained a statement on the reconstruction of the GDL with equal rights of the Lithuanians, Belorussians, Poles and Jews. The territory of the state had to comprise the German-occupied Lithuanian and Belorussian lands of the former GDL. ${ }^{14}$ The next Vilnius document appeared in February 1916. It was an appeal of the Provisional Council of the Confederation of the GDL Piliečiai! (Citizens). ${ }^{15}$ The Poles did not participate in the preparation of this document. ${ }^{16}$ On 21 May the Council turned into a permanent LithuanianBelorussian commission. ${ }^{17}$ The Oberost administration and the Supreme Military Board supported the Lithuanian and Belorussian aspirations iunctim, at the same time subduing Polish influence in the country. The education of Belorussians was treated as one of the means of that struggle. Thus, for the first time in history the basis of the Belorussian educational system was created with the

12 А. Новіна (А. Луцкевіч), 'Палітычные лозунгі беларускага руху', Зборнік 'Намай Hiвы' (Vilnius, 1920), с. 6; J. Turonek, Białoruś pod okupacja niemieckq (Warszawa-Wrocław, 1989), pp. 15-17; O. Latyszonek, Białoruskie formacje wojskowe 1917-1923 (Białystok, 1995), pp. 33-38.

13 А. Луцкевіч, За двадцаць пяць гадоў (1903-1928) (Vilnius, 1928), p. 40; Latyszonek, Biatoruskie formacje wojskowe, pp. 38-39.

14 Didžiosios Lietuvos Kunigaikštijos Konfederacijos Atsišaukimas 1915 gruodžio 19 d. P. Klimas, Dienoraštis 191512 01-1919 01 19, pradedamas P. Bugailiškio užrašais 19150823 (10)-1013 (Chicago, 1988), pp. 328-331.

${ }^{15}$ LVA, f. 383 , ap. 7 , b. 56 , f. 53.

${ }^{16}$ Lopata, 'Lietuvos valstybingumo raida', pp. 71-72.

17 Пратаколы заседаніі Беларускаго Народнаго Камітету, 19160521. LMAB RS, f. 21-2068, f. 6. 
help of the Germans. ${ }^{18}$ A Belorussian teacher-training college was established in Svisloch, and during the occupation it prepared 144 teachers. ${ }^{19}$ In the entire territory of Oberost the number of Belorussian primary schools increased from eight in October 1916 to 89 in the spring of $1918 .{ }^{20}$ The German authorities, formally treating all the local nationalities equally (hence the term 'the liberal period'), did not tolerate the manifestations of Russianness and at the same time prevented any distinct domination of a particular ethnicity.

In the spring of 1916 in the context of the so-called German Los von Russland Campaign there appeared a tendency to distinguish between Lithuanian and Belorussian affairs. ${ }^{21}$ Lithuanians, having detected certain more favourable shifts in German ethnic policy gradually distanced themselves from the concept of the Confederation of the GDL. In their memorandum of 10 of June, addressed to the Chief Eastern Commander, its authors stressed the principle of national freedom and the distinctiveness of their nation. ${ }^{22}$ At the Lausanne conference on 27-29 June the Lithuanian representatives noted in their separate declaration that they would not object to the Belorussians individually deciding their destiny on their own. ${ }^{23}$ Besides, the Belorussians themselves came to Lausanne with their own separate memorandum related to national affairs. ${ }^{24}$

The second half of 1916 was marked by a crisis in the relations between the Lithuanians and the Germans, when the latter began attracting the Poles to their side for pragmatic military considerations. Finally, failing to interest the Russians to start negotiations for a separate peace treaty, the Germans and their supporters declared the independence of Poland on 5 November 1916. The civilian authorities of Berlin pursued a policy of a separate peace treaty with Russia and resorting to various means, including the military ones, exerted pressure on Russia to conclude such a treaty. The

18 Turonek, Białoruś pod okupacja niemiecka, p. 16.

19 Ibid., pp. 17-18.

20 H. Zemke, Der Obersbefehlshaber Ost und das Schulwesen im Verwaltungsbereich Litauen während des Weltkrieges (Berlin, 1936), pp. 101-104.

${ }^{21}$ Lopata, 'Lietuvos valstybingumo raida', pp. 94-95.

22 P. Klimas, Der Werdegang des litauischen Staates von 1915 bis zur Bildung der provisorischen Regierung im November 1918 (Berlin, 1919), pp. 23-25.

${ }^{23} \mathrm{~V}$. Liulevičius, Išeivijos vaidmuo Nepriklausomos Lietuvos atkūrimo darbe (Chicago, 1981), p. 324.

24 Ф. Турук, Белорусское движение (Москва, 1921), р. 23. 
national factor was the first to be exploited to that end. Nevertheless, even after the declaration of Polish statehood, Russia was not going to sign a peace treaty. Further pressure was necessary, however, in the Polish case a collision arose between the national factor and legitimacy - the latter had to be disguised by the former. Observing legitimacy and reconstructing the Republic of the Two Nations, both Berlin and Vienna were to abandon the captured and annexed lands of the Republic. Thus, a very subtle political game had to be played with the Poles in re-establishing their state only in the lands, seized from Russia. ${ }^{25}$

Subtlety had to be applied in respect to the project of Poland's extension eastwards and Vilnius. Though the German authorities had decided to treat Poland as an indirectly annexed territory in that period, the Oberstheeresleitung (Supreme Military Command) was apprehensive of the realization of that project since that would have meant handing over a part of Oberost to the Poles. The Oberstheeresleitung and the authorities of Oberost were interested in the further occupation of that territory, while the expression of the political aspirations of the Lithuanians and the Belorussians were tolerated only as a cover of the annexation.

In order to conciliate the Oberstheeresleitung, the civilian authorities did not define the boundaries of the future Poland. ${ }^{26}$ However, the most important thing was a German communiqué, containing a promise to take care of Lithuania. ${ }^{27}$ Unfortunately, from the German point of view it was wrongly received - it was addressed to Russia rather than to the Oberstheeresleitung.

Freely conducted Polish propaganda for joining Lithuania to Poland and the aforementioned communiqué caused an adverse Lithuanian reaction and protests in the first place in an influential Lithuanian centre in Switzerland. The Germans had to neutralize their actions in order to reconcile to some extent the Poles with the Lithuanians. Therefore the German emissary, Friedrich von Ropp, conducted talks with the then leader of the Lithuanian community in Switzerland, Juozas Gabrys, on 17 December 1916. The visit of the Berlin

25 Germany had occupied the region of Poznań and Austria had taken possession of Galicja. Furthermore, on the basis of ethnic priorities, the Poles could question the subordination of Ślask and Pomorze.

${ }^{26}$ Lopata, 'Lietuvos valstybingumo raida', p. 113.

${ }^{27}$ M. Urbšienè, 'Vokiečių projektai dèl Lietuvos Didžiojo karo metu', Naujoji Romuva, no. 35-36, 1935, p. 632. 
emissary seemed to Gabrys a sort of a German signal to start the campaign to internationalize the Lithuanian question. ${ }^{28}$

On 11 January 1917 a Memorandum on the Re-establishment of Independent Lithuania was submitted to Western diplomats in Berne on behalf of the Council of the Lithuanian People. The German diplomats, by the way, accepted the memorandum with gratitude. ${ }^{29}$ Almost at the same time, on 10 January, a memorandum on Lithuania was presented to the German Ministry of Foreign Affairs and the Oberstheeresleitung by von Ropp. In the document he expressed a doubt on the feasibility of joining Lithuania and Poland disregarding Lithuanian resistance. Finally he proposed to patronize Lithuania militarily and economically and to guarantee its right of self-determination in internal matters. In practice that meant that Germany had to separate Lithuania from Poland and to control them individually. Despite the danger of annexation, the first practical German measures in respect to Lithuania as an independent factor opened certain perspectives for the activity of Lithuanian statesmen.

At first the Germans doubted whether it was worth starting a political game with the Lithuanians. From the viewpoint of the military authorities such a move meant ignoring the Polish factor in Lithuania. The Germans were dissatisfied and displeased with the Poles for not assembling the promised troops. Therefore von Ropp's proposal was accepted unexpectedly. In the middle of January 1917 von Ropp came to Vilnius and held discussions with the Lithuanians and the Oberost officials. ${ }^{30}$ The Lithuanians acquainted von Ropp with the political platform, prepared jointly by the representatives of the Board (Bürio-politine valdyba) A. Smetona, Jurgis Šaulys, Steponas Kairys and Andrius Domaševičius and the members of the National Belorussian Committee Anton and Ivan Lutskevich and Vatsvav Lastavski. These were their main statements: 1) the independence of territories of the GDL and Courland, separated from Russia; 2) a negative attitude to the association with Poland; 3 ) the division of the GDL into three autonomous national areas (Lithuanian, Belorussian and Latvian), and 4) the capital Vilnius

${ }^{28}$ In greater detail, see R. Lopata, "'Tipas apskritai labai dar itariamas, bet reikalingas". Baronas Friedrich von der Ropp ir Lietuvos valstybingumo atkūrimo planai', Proskyna, no. 2, 1992.

${ }^{29}$ Lopata, 'Lietuvos valstybingumo raida', p. 115.

${ }^{30}$ Ibid., 
with two official languages (Lithuanian and Belorussian) belongs to the Lithuanian area. ${ }^{31}$ It must be noted that that was the last joint project for a GDL Confederation.

Von Ropp promised to guarantee the contacts with Berlin, and, what was the most important in that case, the senior officials neither in Berlin nor in Oberost rejected the idea of Lithuanian representation. ${ }^{32}$ Subsequent events showed that the Lithuanians perceived von Ropp's notion 'Lithuanian' too literally. They took it as a sign that the ethnic tendency was getting the upper hand in German politics and that it was time to get rid of the duplicated political line. Though the Lithuanians could not foresee the imminent global and regional changes, the choice of the ethnic line matched the spirit of those transformations.

According to the Belorussians, the aforementioned project of the GDL was not ratified by both sides separately. ${ }^{33}$ In February the Belorussians proposed the Lithuanians that they should take a joint political measure -1 ) to send to the Chancellor a protest condemning the assertion of the Polish public figure Wacław Nemojewski, which contained claims to Belorussian and Lithuanian lands, and 2) to declare their aspirations of independence. The final version of the protest had to be edited by Šaulys and Anton Lutskevich. However, on the day the declaration was edited Šaulys informed Anton Lutskevich that the Lithuanians decided to postpone that declaration for two or three days, without indicating the reason. Instead Šaulys offered to submit a joint memorandum to the head of the Vilnius-Suvalkai authorities (Militärverwaltung WilnaSuwalki) and to ask him to acquaint the authorities of Oberost with its contents. ${ }^{34}$ The document would have called the attention of the German authorities to the leaflets, distributed in the Lithuanian and Belorussian lands by the Polish authorities 'on the Polish historical mission' in these lands, and that the local authorities did not prevent that action. Besides, the memorandum had to contain the common Lithuanian and Belorussian ideals as had been expressed in the suspended protest to the Chancellor. But the Belorussians did not accept the proposed text because it was addressed to incompetent

${ }^{31}$ Baltarusių organizacijos protokolai 1917 m. LMAB RS, f. 21-2069, ff. 7-8.

${ }^{32}$ Lopata, 'Lietuvos valstybingumo raida', p. 115.

${ }^{33}$ Baltarusių organizacijos protokolai 1917 m., LMAB RS, f. 21-2069, f. 7.

${ }^{34}$ Ibid., ff. $7-8$. 
institutions. ${ }^{35}$ The Belorussians again offered a protest to the address of the Chancellor. The Lithuanians, however, disagreed and on 17 February presented a separate protest against the Polish agitation. The authors of the document indicated, among other things, the traditions of the GDL and the readiness of the Lithuanians to continue them. ${ }^{36}$ In the meantime the Belorussians did not quite grasp that Lithuanian move and kept enjoying the former assurances of von Ropp. In the telegrams of 28 February, sent to Paul von Hindenburg and Erich von Ludendorff, they thanked them for the recognition of the equality of the Belorussians in the former lands of the GDL. ${ }^{37}$

Following von Ropp's visit to Vilnius Šaulys, Smetona, Kairys and Lutskevich received German-issued passports for their trips to Berlin and Stockholm. During von Ropp's stay in Vilnius there had been talks about the participation of Lithuanians at a conference of the nations of Russia in Stockholm and about the trip to Berlin in order to start negotiations with the German imperial authorities. For Anton Lutskevich the passport, in his words, was a surprise. ${ }^{38}$ On 2 March the Belorussian committee discussed further actions. In the first place concern and misgivings were expressed that there had been no direct talks with the Belorussians and that the Lithuanians negotiated on their behalf and that they passed to the Germans the name of Anton Lutskevich as a delegate, so far unknown to the Belorussian committee. Taking into consideration the importance of the situation the Belorussians, nevertheless, decided to send Anton Lutskevich. Šaulys being already in Berlin, Kairys acquainted Lutskevich with the aims of the trip. ${ }^{39}$

On 25 March the Belorussians discussed the results of the trip. ${ }^{40}$ Delegate Anton Lutskevich said that for unknown diplomatic reasons the congress had been postponed after Easter, and for the same reasons the talks with the German authorities did not take place. In Berlin he communicated only with the Ukrainians and the Lithuanians. The latter conducted a secret policy and only under pressure did they acquaint their Belorussian colleague with the

35 Ibid., 1. 8.

36 A. Rukša, Kovos dèl Lietuvos nepriklausomybès. Lietuviu-lenku santykiai ir kovu pradžia, t. 2 (Cleveland, 1981) pp. 91-92.

37 Lopata, 'Lietuvos valstybingumo raida', p. 115.

38 Baltarusių organizacijos protokolai 1917 m., LMAB RS, f. 21-2069, ff. 8-9.

39 Ibid., ff. 9, 26.

40 Ibid., f. 25. 
project of the memorandum. Then it became clear that the Lithuanians had been pursuing a purely nationalist policy. They justified their position by the attitudes of the Lithuanians in Russia, America and other neutral countries. After an analysis of the Lithuanian statements Anton Lutskevich stated that none of them contained any reference to Belorussia, and he maintained that the Lithuanian position in Berlin was absolutely nationalist and had nothing to do with the entire region. Having learned about the February Revolution he left Berlin immediately and losing no time hastened back to Vilnius. After his information the Belorussian committee approved his activity in Berlin. ${ }^{41}$

On 22 July 1917 the Belorussians returned again to this episode and in the sitting of the national committee declared that after the trip to Berlin Lithuanian politicians broke off any relations with them. ${ }^{42}$ The Lithuanians had started an overt communication with the Germans. According to the Belorussians, after some time the Lithuanians embarked on an energetic campaign against them. Standing high in German favour they began 'putting into practice a theory' according to which Catholic Belorussians are Lithuanian. All that coincided with the German interests - annexing ethnic Lithuania they would have added the Catholic Belorussia and thus increased their territorial gains. The Poles would have profitted from that situation, etc. - such were Belorussian accusations. In short, the conflict between the Belorussians and the Lithuanians was evident and it had started at the time of the trip to Berlin. The course of the events must have been the following.

According to Smetona, the Germans again started looking for contacts with the Lithuanians early in $1917 .{ }^{43}$ The Stockholm conference was intended as a special demonstration against the Russians. It was to solve the Lithuanian question in the same manner as the Lausanne conference had done with the Polish issue. Having gathered in Berlin the delegates were about to go to Stockholm. However, at that time the Russian Revolution broke out unexpectedly, and the conference lost its significance. After the fall of absolutism there was no more any need to demonstrate against

${ }^{41}$ Ibid.

42 Ibid., f. 10.

${ }^{43}$ Lietuvos Valstybes Tarybos protokolai [LVT] 1917-1918, sud. A. Eidintas ir R. Lopata (Vilnius, 1991), p. 34. 
Russia. The delegates paid a visit to State Secretary Artur Zimmermann and did not present any political issues, except the betterment of internal policy. In a special letter they indicated why the independence of Lithuania was beneficial to Germany as well. Then the events began to develop towards the election of the Lithuanian Council. ${ }^{44}$ The Smetona version of the Berlin episode leads to the conclusion that it was not given any greater prominence by the Lithuanians. Nevertheless, the analysis if the contemporary situation shows that the misjudgement of the Berlin trip could be treated as a mere coincidence, conditioned by the development of the political events, which could not be foreseen beforehand.

The above-presented interpretations of the Berlin trip by the Lithuanians and by the Belorussian show that the Germans invited the Lithuanians with the intention of declaring Lithuanian independence. The February Revolution prevented that, since the German authorities were counting on the Russian government to find a common language and conclude a separate treaty. A question also arises as to the presence of one Belorussian (why only one?) among the Lithuanians. An answer could possibly be found in the aforementioned 'Memorandum on the Re-establishment of Independent Lithuania', issued by Swiss Lithuanians on 11 January. The statements of that memorandum could be used by the Germans in their designs to define the contours of Lithuania. Accordingly the territory of Lithuania had to consist of the gubernias of Vilnius, Kaunas, Grodno, Suvalkai, Courland, the county of Novogorodok of the Minsk gubernia and of the northern area of the gubernia of Łomża - in that territory the Belorussian population made up to 10 per cent. ${ }^{45}$ Proclaiming a state within such boundaries the presence of one Belorussian representative was quite understandable. The supposed proportion of the Lithuanians was about 65 per cent. ${ }^{46}$ Thus the federation with equal rights for the Lithuanians and the Belorussians was problematic from the very beginning. The basis for the Belorussians to get offended was quite sufficient, the more so taking into consideration the way of Anton Lutskevich's enticement to Berlin. Besides, the Lithuanians conducted permanent talks with the representatives of the Prussian authorities Vilius Gaigalaitis

${ }^{44}$ Ibid., pp. 34-35.

${ }^{45}$ Lopata, 'Lietuvos valstybingumo raida', p. 114.

${ }^{46}$ Ibid. 
and Vilius Steputaitis and jointly with them prepared a letter to the Chancellor, mentioned by Smetona. They unwillingly showed it to Lutskevich, and then it became clear that in the German-occupied territory there were no Belorussian Catholics - it was inhabited only by Lithuanians, speaking Lithuanian, Polish and Belorussian. ${ }^{47}$ That letter was handed in to Zimmermann by Grigalaitis. In his turn Lutskevich also wrote a letter to the Chancellor, in which he explained the Belorussian situation and expressed the independence aspirations of the occupied Belorussian-Lithuanian-Latvian country. He handed in that letter to von Ropp. The most important thing in this episode was Zimmermann's agreement in principle namely with the memorandum. It was only after Lutskevich's return to Vilnius that the Belorussians learned about a secret Lithuanian visit to Zimmermann, and at the beginning they were not aware of the object of the talk. From the published Zimmermann's answer to the Lithuanians they found out that the Lithuanians had negotiated on autonomy, while the Belorussians 'stood firm for independence' at that time. ${ }^{48}$ At the same time the Belorussians maintained that the relations had already sharpened in the summer, therefore the incrimination addressed to the Lithuanians did not seem well-grounded for the Belorussians themselves. After all, soon after the Berlin trip they merely stated that the Lithuanian position was purely nationalist and ignored the interests of the entire region. ${ }^{49}$

Taking into account the results of the Berlin trip it could be surmised that their effect on Lithuanian-Belorussian relations was not premeditated, neither were the political events which influenced them. On the other hand, being aware of the deliberate national attitude of the Lithuanians, the opposite could be argued.

Events could have developed in the following way. Von Ropp invited the delegation to Stockholm and eventually to Berlin in the middle of January. Meanwhile the delegates went to Berlin only in March and during that time radical, even global changes took place. The first official aim of the trip to Berlin was to start talks with the German imperial authorities - through von Ropp's mediation to involve the Lithuanians in the internalization of the Lithuanian issue. That was the intent of Gabrys, the Lithuanian delegates and Anton ff. 9,25 .

47 Baltarusių organizacijos protokolai 1917 m., LMAB RS, f. 21-2069,

${ }^{48}$ Ibid., f. 10.

${ }^{49}$ Ibid., f. 25. 
Lutskevich. According to another version, the delegates could have witnesses of the declaration of Lithuania's independence, thus adding legality to that act.

The latter version is most enigmatic. Judging from German actions late in 1916 the imperial authorities considered that after the declaration of Poland's statehood a compromise could be reached with Russia - a balance between legitimism and nationalism, eliminating the basis for the hostilities. On 12 December 1916 Theobald von Bethmann Hollweg declared in the Reichstag that his government was ready to start peace talks with the enemy. Thus began the socalled 'peaceful attack' of Germany. While on the initiative of the mediating United States the warring parties were preparing and declaring their concrete proposals and when it was not yet clear that the peace conditions both of the Central Powers and of the Allies were incompatible and that the enemies were going to fight for victory, there were illusions (on the part of von Ropp and Gabrys) that the Lithuanian issue could be internationalized. ${ }^{50}$ The real goal of the 'peaceful attack' seems to have been only a separate peace treaty with Russia. If one adheres to the opinion that the internationalization of the Lithuanian issue depended directly on Gabrys' initiative and von Ropp's coordination, then, given their endeavours in that period, one must admit that their activity was particularly intense due to the necessity not to lag behind the internalization of Poland's issue in case the Germans and the Russians found a common language. However, the German reaction to the memorandum, presented by von Ropp on 10 January 1917, was apathetic. ${ }^{51}$ At that time neither the Oberstheeresleitung nor the civilian authorities were interested in the issue of Lithuania's internationalization. In their opinion, the plans to declare the GDL would have been a too harsh insult for Russia. In that situation von Ropp doubted whether it would be possible to stick to the terms of the campaign and was even obliged to admit that 'the scheme' devised with Gabrys 'cannot be fully exploited'. ${ }^{52}$ Therefore he proposed changing the tactics and availing themselves of the nationalities congress taking place regularly in Stockholm. He invited Gabrys to Sweden's capital indicating that 'a starting point could be there, and

${ }^{50}$ Lopata, 'Tipas apskritai labai dar ittariamas', p. 120.

${ }^{51}$ Ibid., p. 131.

${ }^{52}$ Ibid. 
not where we had agreed earlier'. ${ }^{53}$ Von Ropp arranged very efficiently the journey of the Lithuanians and Anton Lutskevich, who were to go to Stockholm via Berlin. It could be surmised that they had chosen a sequence of actions more agreeable to the Oberstheeresleitung, namely to declare in Stockholm the same as had been declared in Lausanne in June 1916 in relation to Poland and then to await an analogous outcome.

In organizing the journey, the declaration of Lithuania's independence clearly had not been planned beforehand, and such initiative could have developed spontaneously. After secret negotiations between Russia and the Allies in February 1917, Russia was actually released from the commitments to the national issue. ${ }^{54}$ Thus the whole 'peaceful attack' came to nought, and in the new situation the interests of Berlin and the Oberstheeresleitung became closer. Berlin intended to increase pressure on Russia through its formation of Oberost and to denounce the Allies as an enemy of nations, while the Oberstheeresleitung was going to disguise annexation through independence and to get rid of the prospect of returning those territories to Russia. The Vilnius delegation reached Berlin just in that situation. There appeared press reports that it would be received by Mathias Zimmermann and an act of Lithuania's independence would be passed. ${ }^{55}$ Nevertheless, that did not happen. Smetona's words should be noted - the Russian revolution broke out suddenly while the delegation was in Berlin. ${ }^{56}$ Therefore it is quite believable that the proclamation of Lithuania's independence was prevented by the expectation of the possible consequences of the February Revolution. Berlin again returned to the idea of a separate peace without delay - this time through the Petrograd Soviet. In March and April secret talks took place between Mathias Erzberger and Iosef Kolyshko in Stockholm, in which the possibilities of a separate Russo-German peace treaty were discussed and preliminary peace conditions were formulated. The German authorities had only to collate the peace conditions brought by Erzberger with the annexation programme of the Oberstheeresleitung. ${ }^{57}$ It is

${ }^{53}$ Ibid.

54 Конференция “'оюзников"” в Петрограде 1917 2. Монархия перед крушением 1914-1917. Из бумаг Николая II (Москва-Ленинград, 1927), c. $58-60$.

${ }^{55}$ LVT protokolai, p. 35.

${ }^{56}$ Ibid., p. 34.

${ }^{57}$ Lopata, 'Tipas apskritai labai dar ittariamas', p. 120. 
credible that any meeting with the Lithuanians was postponed due to the negotiations of the Germans with the representatives of the new Russian authorities. In addition, it seems that also at that time the Oberstheeresleitung reminded of itself by its opposition to the talks without the guarantees that the control of Oberost would be maintained. The issue of a compromise between the Oberstheeresleitung and Berlin arose again. This time the resulting decision became a priority for further actions. That decision was reached in a secret session of the Prussian government on 21 March 1917, when Vice-Chancellor Karl Hellferich, basing himself on the suggestions of Bethmann-Hollweg, presented a new German military programme, in which the former principle of a direct annexation of Lithuania and Courland was replaced by that of autonomy. ${ }^{58}$ That statement of the Vice-Chancellor had also to serve as a preliminary protection against the reaction provoked by the talks of the Oberstheeresleitung with the Soviet. That did not help, and in the negotiations the Petrograd Soviet perceived that their interpretation of peace differed from that of the Germans. The new circumstances also made the German civilian authorities simply to resort to concrete actions: to realize a policy of annexation under the cover of the Soviet slogans of 'peace without annexations and contributions' and 'self-determination of nations'. Although initially the civilian German authorities, and the more so the Soviet, considered only Poland as a real object of their actions, eventually the way was opened for the realization of the Oberstheeresleitung plans in Oberost as well.

Due to a compromise between the civilian and military German authorities von Ropp could organize a meeting of the Lithuanians (who had come to Berlin and had nothing else to do) with Zimmermann. The State Secretary stated that 'in the course of the peace negotiations Lithuanian requests and petitions would be "taken fully into account", that tending towards Western Europe they would be able to develop and advance their life substantially in the system of Western Europe'. ${ }^{59}$ By the way, the Stockholm conference also lost its relevance after the February revolution; hopes of a new national policy were pinned on the new government. The general endorsement of the national Lithuanian idea, expressed by Zimmer-

58 Ibid., pp. 120-121.

59 J. Šaulys to V. Gaigalaitis, letter of 23 March 1917, LNMMB RS, f. 50, s.v. 86 , f. 4. 
mann in the above-mentioned meeting with the Lithuanians, corresponded to the plan of pressurizing Moscow further. If the Russian Provisional Government supported the Estonian Maapäev or the Latvian Landtag and their aspirations in one way or another, why could not the Germans support Lithuanians and their aspirations? After all, the basis was the same intentions of national determination.

Germany, seeing greater chances of success, started to exploit the new situation for its own benefit. A separate peace treaty with Russia remained its main objective. At the beginning of the war the Chancellor had resolved even to cede the occupied territories for the peace treaty ${ }^{60}$ However, as Russia obstinately kept silence, the Germans took root in the occupied territories, and the national principle became established in the policy of the great powers, the retention of the occupied territories seemed increasingly real for Germany. Paradoxically, the possibility of retaining the occupied territories was afforded by a wider application of the national principle. The Germans considered that in the framework of the principle of national self-determination the Lithuanians could count only on the right of an independent ethno-cultural development due to their insufficient potentialities of civilization/statehood. Following the achievement of a separate peace with Russia on the principle of determination, the transformation of the right of the ethnic nation into that of the state would have occurred in the competence of Germany. There appeared a chance to implement the annexation objectives of the generals of the Oberstheeresleitung via a compromise. Although at the Bingen conference on 5 April the military required to annex the territory of Oberost without delay, Berlin perceived that annexation became an outworn policy after the slogans on self-determination of nations spread by the February Revolution and in particular following the USA's entry into the war on the side of the Allies on 7 April. The compromise meant a set-up of councils of the occupied countries, it was dictated by the need 'to formalize the independent states', which on their own (without German instigation) would express their willingness to join the Reich. That was the essence of the so-called 'Lithuanian' policy of the annexation of Lithuania. Its initiator was the German Chancellor.

${ }^{60}$ All the time dreaming about a separate peace treaty, the German Chancellor did not record any eastern territorial acquisitions until early 1917; cf. M. Bienhold, Die Entstehung des Litauischen Staates in den Jahren 1918-1919 im Spiegel Deutscher Akten (Bochum, 1978), p. 30. 
The Lithuanians' visit to Zimmermann was also a component of that new trend. A significant German compromise was achieved at the conference of civilian and military authorities in Kreuznach on 23 April 1917. There the idea to expand Poland in the direction of Vilnius was abandoned. That conference ensured the autonomy of Lithuania in case the Germans stayed there. ${ }^{61}$ According to the German legal historian Marian Bienhold, the annexation idea, initiated by the chancellor, had to be treated as a guideline for German policy until the end of the war. ${ }^{62}$

After the Berlin trip the contacts between the national Belorussian committee led by Anton Lutskevich and the Lithuanians actually, though not abruptly, were broken off. ${ }^{63}$ The Belorussians continued to maintain contacts with Lithuanian radicals on the basis of the conception of the region. A number of discussions took place, attended by Belorussian, Lithuanian, Polish and Jewish radicals. ${ }^{64}$ In these talks it became clear that the Lithuanians applied the conception of historic lands only to the German-occupied territories. The Belorussians disagreed: Anton Lutskevich declared that the Belorussians could talk about the establishment of the state in the circumstances of the occupation only when despotism and 'oppression of non-Russians' reigned in Russia and a hope of freedom was seen in the separation of at least a part of Belorussia from Russia in order to establish a Belorussian Piedmont there. Now when the hour of freedom came to Russia, the local Belorussians could no longer endure the division of the nation into two parts and yearned for independence for the whole of Belorussia eventually in close unity with Lithuania and in federation with other neighbours. ${ }^{65}$ After that declaration there were no more meetings of the radicals. In his essay of 22 July Anton Lutskevich announced that the Lithuanians became more bitter enemies of the Belorussians than the Poles. ${ }^{66}$ That statement is slightly astonishing, since in his analysis of the development of Lithuanian and Belorussian contacts during half a year did not present any new serious cases of Lithuanian antiBelorussian actions in comparison with the statement of 25 March.

${ }^{61}$ Ibid., p. 39.

62 Ibid., p. 37.

${ }^{63}$ Baltarusių organizacijos protokolai 1917 m., LMAB RS, f. 21-2069, f. 10.

${ }^{64}$ Ibid., f. 11.

${ }^{65}$ Ibid.

${ }^{66}$ Ibid., f. 14. 
He merely gives a more critical evaluation of the behaviour of the Lithuanians during the Berlin trip, in particular with respect to the theory of the Lithuanian character of Catholic Belorussians.

Meanwhile, the formulation of that theory is to be directly associated with the tendencies among German politicians to distinguish between Lithuanian and Belorussian issues. Those new trends appeared in the spring of 1916 and became clearly obvious in the middle of the year. According to Klimas, on 8 August 1916 he was given a task of gathering and compiling the data on ethnic boundaries. ${ }^{67}$ The assignment was received from the 'Lithuanian diplomacy group' (Lietuvos diplomatijos grupe) as a direct aftermath of the recent Lausanne conference. The Lithuanian delegate to that conference Šaulys forwarded that request to the Lithuanian politicians in Vilnius. After the talks abroad an agreement was reached to establish a kind of Lithuanian embassy in Berlin. It had to be an information bureau to disseminate the attitudes of the Lithuanians themselves. At the Lausanne conference the Lithuanians presented an alternative to the civic variant of the GDL's statehood and it had to be reflected in the Lithuanian propaganda. The inscriptions of 10 and 29 September in Klimas' diary show that at that time he was working on his Russisch-Litauen. Statistisch-etnografische Betrachtungen, which was published under the pseudonym of K. Werbel in Stuttgart in 1916. This book contained the theory of the Lithuanian character of Belorussian Catholics fully and consequently on the basis of scholarly arguments. The German support of the ethnic trend was attested by the note in the diary on 23 September: 'The work is urgent and one German Social-Democrat has edited (the translation) and is going to publish it in Southern Germany. The new theme seems to be interesting'. The inscription of 26 October shows that at that date the work had been finished. ${ }^{68}$ Consequently, the Belorussian reaction to the new tendencies in Lithuanian politics followed nearly a year later.

The ideas of GDL statehood became overtly adventurous due to various problems related to the Belorussians and mostly due to the belated German understanding of the relations between the Belorussians and the Russians and the division of the Belorussian territory along the settled front line. Even the German military 
authorities were more readily inclined to rely on the theory of the Lithuanian character of Western Belorussia. In their activity the Belorussians failed to persuade the Germans that they were a significant and, what was more important, a flexible force. Their greatest problem was the absence of the national right wing. Meanwhile, according to Lopata, the Lithuanian 'political potential was sufficient for a serious modelling of different perspectives of Lithuania's future from the autonomy and independence of ethnic Lithuania to the independence of a unitary or confederate GDL' ${ }^{69}$ When the Germans passed over to the 'Lithuanian' policy, a movement for the election of a Council on the national basis started in the country. The appearance of the Council marked a new phase in the relations between the Lithuanians and the Belorussians.

\section{Author Details}

Edmundas Gimžauskas graduated from the Department of History, University of Vilnius in 1996. In 2001 he obtained a doctor's degree for his dissertation on the relations between the Lithuanians and Belorussians in the early twentieth century. These issues remain a sphere of his research, conducted at the Lithuanian Institute of History.

Address: Department of 20th-Century History, Lithuanian Institute of History, Kražiu 5, LT-2001 Vilnius, Lithuania.

Email: istorija@comliet.lt

\section{BALTARUSIUQ VEIKSNYS MODERNIOSIOS LIETUVOS VALSTYBĖS GENEZĖJE 1915-1917 METAIS}

Santrauka

\section{EDMUNDAS GIMŽAUSKAS}

Straipsnyje siekiama pristatyti baltarusių vaidmeni modernios Lietuvos valstybės genezèje 1915-1917 metais. Šio laikotarpio lietuvių - baltarusių santykių tema istoriografijoje sulaukè dèmesio tik visai neseniai.

Pirmojo pasaulinio karo pradžioje vokiečių kaip lemiančio geopolitinio faktoriaus dèka jų užimtose žemėse pirmą kartą po 1795 m. vèrèsi reali Abieju Tautų Respublikos atkūrimo galimybè. Tačiau ji neiejjo i vokiečių

${ }^{69}$ Lopata, Lietuvos valstybingumo raida, p. 179. 
planus. Pradžioje jie tepalaike Lietuvos istorinio valstybingumo atkūrimo iliuziją užimtose buvusios LDK žemėse. Šios politikos terpeje atsirado vietos ir lietuvių bei baltarusių inteligentu praktinès politinès veiklos pradmenims. Nuo 1916 m. „Los von Russland“ kampanijos pradžios galètume kalbèti apie paviešintus lietuviu ir baltarusiu valstybingumo siekius. Atsižvelgiant $\mathfrak{i}$ kariaujančių šalių praktinès politikos vingius, lietuvių politinejje linijoje lygiagrečiai buvo taikomos istorinio ir etnografinio valstybingumo formulès. Po $1916 \mathrm{~m}$. lapkričio 5 d. Lenkijos valstybingumo deklaravimo lietuvių etnografinis modelis èmè igauti vis didesni prioriteta. Planuojama etnografinè Lietuvos valstybè teritoriniu atžvilgiu rytuose faktiškai sutapo su istorine „Tikraja Lietuva“. Tai buvo pagrindas išlaikyti daugiau mažiau konstruktyvius santykius su baltarusiais, dèl objektyviu priežasčių pasilikusiais ištikimais istorinei formulei. Po Vasario revoliucijos Rusijoje baltarusiams ėmus reikalauti visos LDK istorinio valstybingumo, santykiai nutrūko. Naujas santykių etapas prasidèjo 1917 m. rudeni lietuviams išsirinkus Lietuvos Tarybą.

Received 10 October 2001 